\title{
DESIGN OF AN ART MUSIC RELATED ESP COURSE SYLLABUS IN THE CONTEMPORARY CONTEXT
}

\author{
Darko Kovačević \\ University of East Sarajevo, Faculty of Electrical Engineering/Academy of Music, Bosnia and Hercegovina \\ E-Mail: dax1978@gmail.com; darko.kovacevic@etf.ues.rs.ba
}

\begin{abstract}
In the case of any ESP course, at any level, a careful syllabus design is of critical importance for its successful and purposeful implementation. After the introductory chapters, dealing with the key definitions and issues of ESP and art music related ESP, in the central part of this paper a design of an art music related ESP course syllabus is presented in detail, with the naming and description of all the steps and components included both in the design process and the subsequent practical performance of the course in direct work with students. The entire described process is planned with the full awareness of the contemporary life and circumstances, especially regarding the development of information technologies and information society and the consequences of such a development to the notions and concepts of learning, studying and teaching.
\end{abstract}

Key words: ESP, art music, course, syllabus, design, teaching, learning

\section{INTRODUCTION TO ESP}

When comparing English for Special Purposes (ESP) with General English Language, Helen Basturkmen uses rather metaphorical expressions, stating that "whereas General English Language teaching tends to set out from point A toward an often pretty indeterminate destination, setting sail through largely uncharted waters, ESP aims to speed learners through to a known destination", with the emphasis on "going from A to B in the most time- and energy-efficient manner" (Basturkmen 2006: 9). However, she notices that "within ESP there are proposals and counterproposals, arguments and counterarguments about the nature of the destination (views of what is meant by knowing a language for special purposes) and the best way of getting there (views of learning and teaching)", so that, "although practical in orientation, ESP, like any other language teaching enterprise, is based on ideas about the nature of language, learning, and teaching" (Basturkmen 2006: 9).

Regarding the definitions of ESP, the contents of the ones which can be found in present literature is more-less similar. Thus, according to Paltridge and Starfield, "English for specific purposes (ESP) refers to the teaching and learning of English as a second or foreign language where the goal of the learners is to use English in a particular domain" (Paltridge and Starfield 2013: 2). The definition is similar to the one which identifies, as the essential feature of ESP, that it focuses "on studying and teaching specialized varieties of English, most often to nonnative speakers of English, in advanced academic and professional settings" (Bawarshi and Reiff 2010: 41) or observes ESP as "the role of English in a language course or programme of 
instruction in which the content and aims of the course are fixed by the specific needs of a particular group of learners"(Richards and Schmidt 2010: 198). Finally, Day and Krzanowski define ESP within the range of words included in the abbreviation, stating that it "involves teaching and learning the specific skills and language needed by particular learners for a particular purpose", so that "the P in ESP is always a professional purpose - a set of skills that learners currently need in their work or will need in their professional careers" (Day and Krzanowski 2011: 5).

The fact which emerges from all the given definitions of ESP is that a basic and key characteristic of an ESP course, in any field of human activity, is the orientation towards the specific needs and purposes determined by the learners and their educational or professional profile. Due to that, ESP courses primarily focus on the language, skills, and genres aiming to enable learners to perform specific activities and tasks in English, within a certain field of educational or professional interest. It is typical, especially at the university level, i.e. within the curricula of higher education institutions, that ESP students are adult learners, and a homogeneous group in terms of learning goals and the set of needed language skills (in terms of language proficiency, acquired through previous education, such a homogeneousness mostly does not exist within such a group). Due to the mentioned, it can be said that the "key issues in the teaching of English for specific purposes are how to identify learner needs, the nature of the genres that learners need to be able to produce as well as participate in, and how we can know that our learners have been able to do this successfully, and, if not, what we can do to help them to do this" (Paltridge and Starfield 2013: 2).

\section{ART Music RELATED ESP}

Art music, sometimes also known as "classical" or "serious" music, presents the music which "has the features of authentic art to a largest degree" (see Plavša 1972: 617 for more details), so that it stands as an opposition to popular music and its numerous styles and genres, and "is distinguished from it both on the basis of the stated artistic characteristics and on the basis of the continuity of written records which has been existing from the creation of early notation systems to the present day, visible in the form of sheet music (music scores) of musical composition" (Kovačević 2017: 35).

In relation to that, "art music related ESP presents a specific type of ESP where the emphasis is on mastering the use of specific terminology and linguistic structures which are considered as appropriate, understandable and professional within the discourse community of people professionally or educationally involved in art music" (Kovačević 2018: 336). Within the overall corpus of different branches of ESP emerging from various educational or professional orientations, such as Business English, Legal English, Aviation English, English for Medical Purposes, English for Science and Technology, Technical English, etc., the English for professional and educational use in different (theoretical and practical) fields of art music somehow has not managed to establish its place completely, at least according to the available literature in the field. The main reason for that is, probably, the fact that art music is primarily observed in relation to the practical acts of musical performance, while the theoretical aspects of art music (see Kovačević 2018: 333-334 for more detail) remained neglected and below-the-radar in terms of serious and detailed linguistic investigation and research. However, due to both the expansion of art music related ESP courses at the academies of music or similar higher education institutions and the indisputable fact that a 
specific form of English language for communication within the discourse community of persons professional or educationally involved in art music really exists, the situation will probably change in the years to come.

To comprehend both the key features of art music related ESP and its learning outcomes, presented through the design of an ESP course syllabus, it is, at first, necessary to give a brief overview of music education at the university level. Namely, in the most general terms, higher education in music is divided into theoretical-pedagogical departments, dealing with different theoretical disciplines and subjects of music and the teaching of these disciplines and subjects (such as Harmony, Theory of Music, Solfeggio, Musical Forms, Counterpoint, History of Music, Musical Arranging, Musical Composition etc.), and vocalinstrumental departments, dealing with vocal and instrumental performance (i.e. singing or playing on different instruments). Of course, in a broader sense, they have a lot of features (subjects and disciplines) that they share, so that the studying on a theoretical-pedagogical department implies the compulsory lessons in gaining knowledge and skills in the piano playing (and, in some cases, on some other (second) instrument as well), while the studying on a vocal-instrumental department implies mastering of a certain number of theoretical disciplines, especially in terms of History of Music and different aspects of musical analysis. It can be said that, regardless of the differences in subjects and disciplines taught during the study, as well as of its final outcome, the students of both theoretical-pedagogical and vocalinstrumental departments share some necessary, theoretical knowledge about the fundamental concepts of art music, and that knowledge, observed linguistically, presents the essence of the specifically musical discourse in use among them (and their teachers) in their mother tongue. At the same time, from the perspective of teaching ESP, it presents a common denominator from which an ESP course syllabus might be started (and subsequently developed and adjusted to meet more specific needs).

\section{Art Music Related ESP COURSE Syllabus Design}

It would be common for an art music related ESP course to start by identifying the English language translation equivalents of basic music terms, expressions and phrases, presented through appropriate textual and/or audio-visual materials. The similar transfer of knowledge from the students' mother tongue to English should also be performed in relation to lexico-grammatical and discursive features of the texts within the art music register, covering the most significant text types and genres, together with the topics that might be found in them. However, in such a transfer, it is necessary to act carefully, by planning and making a sustainable balance between the language learning and objective needs, components, requirements and limitations of the teaching process, by organising the contents of lessons into the units which deal with various aspects and dimensions of language, such as morphology, syntax, semantics, pragmatics, discourse and genre analysis. There are also, other, rather extracurricular components to be considered (mostly in the status of aforementioned limitations), including the students' knowledge of general English and the number of lessons allocated to ESP within a semester or an academic year. Relating to the latter component, the lessons allocation from the Academy of Music at the University of East Sarajevo will be used, with the ESP course taught in the first two years of undergraduate study (first four semesters), organised into two two-semester subjects (English Language 1 and 2), with two lessons (2x45 minutes) per week in all four semesters. Due to 
the fact that a semester lasts for 15 weeks, it makes a total of 120 lessons weekly distributed within the first two study years.

One more extracurricular component that should always be kept in mind is embedded in the overall conditions of the living in present time, and the needs that such a living imposes to its consumers. Namely, the development of information technology and the establishment of the Internet as an informational highway which connects the entire world (either at a low cost or free of charge) and enables a fast and almost unlimited exchange of information and data search has greatly changed the way in which the students perceive the world they are in (with English language as its lingua franca) and, accordingly, the system in which they study as a part of that world. The versatility and multimediality of available information resources have drastically changed the concepts of both teaching and learning and imposed the need and opportunities for the obtaining, presenting and use of appropriate course materials. In the concrete case of teaching ESP, it is necessary to be constantly up to date with the newest and current trends, information and topics and to introduce and present the materials in different ways and through different resources, with a clear emphasis on relevant lexico-grammatical and discursive features.

As it has already been said, the starting move in the design of an art music related ESP course should be the identifying of the art music terminology in mother tongue which can be considered as a common, shared knowledge for all the students, regardless of the department, course, or the year of study at which they are attending lessons. The insight into the curriculum has shown that such terminological knowledge exists within the fundamental theoretical art musical subjects and fields, such as History of Music, Solfeggio, Theory of Music, Harmony, Musical Forms and Music Instruments. Through appropriate textual and audio-visual materials, the students should gradually be made aware of semantic and translational equivalents of the terms in the English language. In that process, there is a mitigating circumstance of the overall standardisation of music terminology all over the world, performed so thoroughly that most translations of key terms from the field of art music have their place in bilingual dictionaries of general English. On the other hand, it has led to the creation of bilingual or multilingual music dictionaries (where English is the second language), as well as of numerous bilingual or multilingual terminological databases, glossaries, etc.

After that, initial move, the next two moves throughout an art music related ESP course should be the adjustment of lesson materials to the more specific needs of students from different departments, and, in accordance with that, the defining and precising of the course's specific learning outcomes, outside the framework of both general English knowledge and the mastering of specific lexico-grammatical issues and discursive issues. However, in order to perform that properly, even before the beginning of the practical implementation of a course, the contents of the lessons and additional teaching materials should be planned and prepared very carefully, and subsequently implemented in the teaching process, so that it simultaneously covers the most significant lexico-grammatical issues of art music English and the basic notions of semantics and pragmatics as well. Of course, for the latter, it is necessary for some time in which the students have become more proficient in dealing with textual and audio-visual materials related to art music to pass. Relating to this, there are the issues of overall opportunities and purpose dictated by the familiarity of a specific student group with general English (which greatly affects their possibility to deal with art music English) and the total allocated and available time for the lessons and activities outside the classroom within the entire curriculum (which is, in the case of higher education institutions where the ESP is 
taught, usually primarily oriented towards gaining a certain professional knowledge), and the teaching subjects schedule made pursuant to such an orientation on the level of an academic semester or year.

In dealing with what has been mentioned, it is important to use a balanced combination of authentic textual and audio-visual materials, as the main classroom lesson materials and as resources for different exercises and activities, both curricular and extracurricular. Such materials can be used for all the components of ESP teaching. Primarily, there are the understanding and comprehension of written texts, which, in a period of time and after some experience and knowledge has been gained by the students, might lead to the recognition and identification of the structure and organisation of longer pieces of text written in the English language on various art music related topics, together with the analytical insight into their semantic and pragmatic features. Additionally, it might become possible for them to distinguish the different genres which exist within the textual materials on art music.

On the other hand, the purpose of such materials is to be used as a role model for the gaining and improvement of students' writing, starting with the basic concepts of morphology (enriched with art music terminology) towards the structuring of sentences and, finally, their arrangement into textual paragraphs which are coherent, cohesive and correct in terms of grammar.

Finally, the use of (primarily authentic) audio-visual materials in which the text, images, video and sound (of spoken discourse on art music, consisting of presentations or lectures by professionals and experts who are native speakers, or of recorded conversations of such experts or professionals) appear together, in a multimedia experience, may, on the one hand, improve the students' listening skills, while functioning together with textual materials and guided classroom and extracurricular tasks and activities it may give its significant contribution to the improvement of the students' speaking skills in relation to different topics from the field of art music.

Everything that has been mentioned in the previous paragraph should also improve both the process of translation teaching to students (both from the mother tongue to English and vice versa) and their translation skills and knowledge.

To design and implement an ESP course syllabus covering the professional and educational fields of art music, it is necessary to be aware of the most common textual genres and types within the wide corpus comprising the entire discourse of art music. In this sense, the main categories are: books on art music (theoretical studies, historical overviews, dictionaries and encyclopaedias, collections of texts written by one or more authors), scientific and professional papers (from proceedings and journals) and prefaces and afterwords from printed editions of sheet music) (Kovačević 2018: 338). It is also important to identify the most significant topics which might be found within the discourse. Such identification must be made with care, because the texts on art music, especially within longer articles, studies and books, are often written interdisciplinary, so that the art music related themes are interwoven, connected or associated with the themes from various fields of art, science and humanities, such as painting, sculpture, physics, acoustics, general history, philosophy, aesthetics, literature, linguistics, etc. According to Kovačević, it is possible to classify the topics in three major categories: 
- life and creation of composers, with the emphasis on their education, works, compositional techniques and the place they occupied within the epoch and style they belonged to;

- introduction, presentation and definition of musical terms, instruments and phenomena;

- analysis of musical works on the basis of different parameters (melody, harmony, form, performance aspects, genre) or their combinations. (Kovačević 2018: 338)

In an ESP course syllabus design process, regardless of the type and quantity of teaching materials, in order to keep up with the present trends and important and relevant topics and, at the same time, to maximise the information association and connection between the professional materials in English and the ones in the students' mother tongue, it is important to use the materials which are current and up to date. That should be done in such a manner that, within the syllabus, the overall topics of a unit, together with the lexicogrammatical components, teaching assignments and goals generally arising to and associated with its contents remain fixed, while the very contents in terms of textual and audio-visual materials remain subject to change or adaptation, depending on the needs and availability of new materials. In that way, the actuality of a course is preserved, while at the same time, a great deal of flexibility is provided in its creation and implementation.

In the text that follows, a rough outline of an art music related ESP course syllabus will be given. It is created within the given (available) parameters in terms of the total course duration, its organisation and weekly and annual number of lessons (2 study years, 2 subjects, 60 lessons per year (30 weeks x 2 lessons).

In the first year of study (the subject English Language 1), the selection of textual and audio-visual materials will be based on the students' common knowledge of different fields and subject of art music, with the emphasis on adopting the terminology and lexicogrammatical features of texts written in English through their association with similar materials written in the mother tongue. At the same time, a review of general English morphology and basic syntax will be done, through the overview of the parts of speech and their features and of the essential rules regarding the sentence organisation in English. Due to that, the units will consist of the selection of textual and audio-visual materials covering the following fields: History of Music, Musical Instruments, Theory of Music, Harmony, Counterpoint, Musical Forms, and Solfeggio. The selected textual materials, as the essential constituent of the course, will come from various sources, but primarily from different textbooks, books, professional articles and music encyclopaedias, due to the relevance of such sources and the precision and clarity of language in them. In the case of longer texts, the parts which make logical, meaningful and well-structured units for themselves will be taken as excerpts. If necessary, the texts will be adjusted and adapted by the teacher, who will also create different activities and exercises on the basis of them, and also find, select or create appropriate audio-visual materials (videos, presentations, lecture recordings, etc.) to be used in the classroom during the lessons, especially in terms of listening and speaking, and for extracurricular activities and homework. On the other hand, within the revision of morphology and essential syntax covering the parts of speech and essential sentence types, some lexico-grammatical features which are specific for texts on art music will be introduced and explained, such as the modification of nouns and specific use of verb tenses in different situations. In that process, the students' writing skills will gradually be becoming developed and improved, by starting from basic grammar exercises, towards the answering to questions based on textual or audio-visual materials to the writing of short 
essays on different art music related topics. Translation exercises will also be performed, on shorter pieces of texts, in both directions and with special care on the proper use of terminology and the solving of difficulties and problems which may arise in the translation of complex sentences or entire paragraphs due to the differences between the students' mother tongue and English.

The syllabus in the subject English Language 2, taught in the second year of study, will continue in the same manner, but without its grammar part and with the primary emphasis on textual materials and their discursive, semantic and pragmatic features. As a difference from the ones selected for the first year of course, the texts used in the second year will be organised and classified into units primarily on the basis of their genre. The classification will generally include the following genres: overview, review, interview, encyclopaedic unit, musical analysis, abstract/summary, journal article and magazine article. The texts will be used without any trimming, regardless of their length, and adapted by the teacher only if that is really necessary (so that their language, which is often more complex and definitely not so clear and precise as the one in the texts to be used in English Language 1 remains intact), while the accompanying exercises and activities will be created on the basis of their contents. On the same basis, appropriate audio-visual materials will be selected for working in the classroom and at home. The texts belonging to the named genres will be taken from various publications available both as hard copies and online, and the efforts will be made to find and use the materials which are current, fresh, actual and related to the present time events, trends and phenomena in the field of art music. Besides the development of students' reading comprehension and speaking and listening skills through their contact and work with selected textual and audio-visual materials, special attention will be paid on the further development of their writing skills, i.e. on the writing of longer texts belonging to the genres taught and analysed in lessons. However, on the basis of practical needs imposed by the students, i.e. the ones who study on a theoretical-pedagogical department and the ones from vocal-instrumental departments, and the practical needs of their future professional activity, the differences will be made to some degree regarding the genres in writing of which the students from each of the departments should become proficient. More precisely, the students of theoretical-pedagogical departments will be required to become equally proficient in all the genres included in the course, while for the students of vocalinstrumental departments the special emphasis will be on overview, review and musical analysis. The translation practice will continue in the same manner as in the first year of the course, but now including much longer (and, linguistically, more complex) textual materials.

For the purpose of clarity, the key and general features of described art music related ESP course syllabus will be presented in the form of a table: 
Table 1 Art related ESP course design

\begin{tabular}{|c|c|c|c|}
\hline \multicolumn{4}{|c|}{ ENGLISH LANGUAGE 1} \\
\hline $\begin{array}{c}\text { Course } \\
\text { duration }\end{array}$ & $\begin{array}{l}\text { Units - professional } \\
\text { fields to be covered } \\
\text { by textual and } \\
\text { audiovisual materials }\end{array}$ & $\begin{array}{c}\text { Selection of textual and } \\
\text { audio-visual materials }\end{array}$ & Grammar \\
\hline $\begin{array}{c}2 \text { semesters } \\
2 \times 30 \text { lessons } \\
2 \text { lessons per } \\
\text { week } \\
(2 \times 45 \text { min })\end{array}$ & $\begin{array}{l}\text { History of Music; } \\
\text { Musical Instruments; } \\
\text { Theory of Music; } \\
\text { Harmony; } \\
\text { Counterpoint; } \\
\text { Musical Forms; } \\
\text { Solfeggio. }\end{array}$ & $\begin{array}{c}\text { Textual materials: } \\
\text { excerpts from textbooks, } \\
\text { books, professional articles } \\
\text { and music encyclopaedias. } \\
\text { Audio-visual materials: } \\
\text { videos, presentations, } \\
\text { lecture recordings. }\end{array}$ & $\begin{array}{c}\text { Morphology: } \\
\text { Nouns and Pronouns; } \\
\text { Verbs (tenses, passive } \\
\text { voice, indirect speech, } \\
\text { conditionals); } \\
\text { Adjectives and Adverbs; } \\
\text { Articles; } \\
\text { Prepositions; } \\
\text { Conjunctions, } \\
\text { Syntax: } \\
\text { Word order; } \\
\text { Models of affirmative, } \\
\text { negative and interrogative } \\
\text { sentences; } \\
\text { Complex Sentences. }\end{array}$ \\
\hline $\begin{array}{c}\text { Specific } \\
\text { lexico- } \\
\text { grammatical } \\
\text { features }\end{array}$ & $\begin{array}{c}\text { Reading and listening } \\
\text { goals }\end{array}$ & Speaking goals & $\begin{array}{c}\text { Writing and translation } \\
\text { goals }\end{array}$ \\
\hline $\begin{array}{l}\text { Terminology; } \\
\text { Word } \\
\text { formation } \\
\text { Modification } \\
\text { of nouns } \\
\text { ("musical", } \\
\text { adjectives); } \\
\text { Use of verb } \\
\text { tenses in } \\
\text { context within } \\
\text { the art music } \\
\text { discourse. }\end{array}$ & $\begin{array}{c}\text { Detailed } \\
\text { understanding of } \\
\text { shorter written and } \\
\text { spoken texts and the } \\
\text { concepts and ideas } \\
\text { presented in them. }\end{array}$ & $\begin{array}{l}\text { Capacity to answer the } \\
\text { questions related to } \\
\text { presented and discussed } \\
\text { textual and audio-visual } \\
\text { materials and to discuss } \\
\text { various art music related } \\
\text { topics. }\end{array}$ & $\begin{array}{c}\text { Writing: } \\
\text { Capacity to answer the } \\
\text { questions related to } \\
\text { presented and discussed } \\
\text { textual and audio-visual } \\
\text { materials in written form } \\
\text { and to write essays on } \\
\text { various art music related } \\
\text { topics. } \\
\text { Translation: } \\
\text { Translation of shorter } \\
\text { professional texts in both } \\
\text { directions. }\end{array}$ \\
\hline
\end{tabular}




\begin{tabular}{|c|c|c|c|c|c|}
\hline \multicolumn{6}{|c|}{ ENGLISH LANGUAGE 2} \\
\hline $\begin{array}{l}\text { Course } \\
\text { duration }\end{array}$ & \multicolumn{2}{|c|}{$\begin{array}{c}\text { Units - professional fields to } \\
\text { be covered by textual and } \\
\text { audiovisual materials }\end{array}$} & \multicolumn{2}{|c|}{$\begin{array}{l}\text { Selection of textual } \\
\text { and audio-visual } \\
\text { materials }\end{array}$} & Text analysis \\
\hline $\begin{array}{l}2 \text { semesters } \\
2 \times 30 \\
\text { lessons } \\
2 \text { lessons per } \\
\text { week } \\
(2 \times 45 \mathrm{~min})\end{array}$ & \multicolumn{2}{|c|}{$\begin{array}{c}\text { Genres } \\
\text { Overview; } \\
\text { Review; } \\
\text { Interview; } \\
\text { Encyclopaedic unit; } \\
\text { Musical analysis; } \\
\text { Abstract/summary; } \\
\text { Journal article; } \\
\text { Magazine article. }\end{array}$} & \multicolumn{2}{|c|}{$\begin{array}{c}\text { Textual materials: } \\
\text { Authentic and actual } \\
\text { materials taken from } \\
\text { various publications } \\
\text { (journals, magazines, } \\
\text { collections of papers, } \\
\text { book) available both } \\
\text { as hard copies and } \\
\text { on the Internet. } \\
\text { Audio-visual } \\
\text { materials: } \\
\text { videos, } \\
\text { presentations, lecture } \\
\text { recordings. }\end{array}$} & $\begin{array}{l}\text { Discourse analysis; } \\
\text { Semantics; } \\
\text { Pragmatics. }\end{array}$ \\
\hline \multicolumn{2}{|c|}{$\begin{array}{l}\text { Reading and listening } \\
\text { goals }\end{array}$} & \multicolumn{2}{|c|}{ Speaking goals } & \multicolumn{2}{|c|}{$\begin{array}{c}\text { Writing and translation } \\
\text { goals }\end{array}$} \\
\hline \multicolumn{2}{|c|}{$\begin{array}{l}\text { Detailed understanding of } \\
\text { longer written and spoken } \\
\text { texts and the concepts and } \\
\text { ideas presented in them. } \\
\text { Identification of different } \\
\text { genres and their features. }\end{array}$} & \multicolumn{2}{|c|}{$\begin{array}{l}\text { Capacity to give long and } \\
\text { detailed answers the } \\
\text { questions related to } \\
\text { presented and discussed } \\
\text { textual and audio-visual } \\
\text { materials and to discuss and } \\
\text { present various art music } \\
\text { related topics. }\end{array}$} & \multicolumn{2}{|c|}{$\begin{array}{c}\text { Writing: } \\
\text { Capacity to write longer } \\
\text { texts on art music in } \\
\text { different genres introduced } \\
\text { and analysed in lessons } \\
\text { Translation: } \\
\text { Translation of longer } \\
\text { professional texts in both } \\
\text { directions with the ability to } \\
\text { identify and solve potential } \\
\text { translational difficulties and } \\
\text { problems. }\end{array}$} \\
\hline
\end{tabular}

\section{CONCLUSION}

There are various parameters which should be taken into account in the designing of an art music related ESP course syllabus to be used at appropriate higher education institutions. Besides those specifically professional and lexico-grammatical ones, it is also very important for a teacher - course creator to be fully aware of all the informational opportunities provided by the present time technological development and the way in which those opportunities influence how the students see, comprehend and approach the processes of teaching and learning. At the same time, the creator also has to be aware of all the available and possible resources which can be used in a course, and the ways in which they can be used. Due to that, the courses should be based on the students' common professional 
knowledge, regardless of the department they study at, and the association and connection of that knowledge with terminologically and topically similar concepts in English, through the work on authentic textual and audio-visual materials produced by native speakers who are experts or professionals in different fields of art music. However, it should be done in a rather dynamical manner, allowing the teacher the opportunity to change or introduce the new, more actual textual materials in the course within a more general and fixed unit without doing any radical change or harm to its contents, nature and purpose. If such a course is implemented carefully and thoughtfully, it might lead to a gradual and sustainable development of all the language skills required for professional information exchange within the art music discourse community (reading, speaking, listening, writing, translation).

\section{REFERENCES}

Basturkmen H. (2006). Ideas and Options in English for Special Purposes. Mahwah, N.J: Lawrence Erlbaum Associates, Publishers.

Bawarshi, A. S. and Reiff, M. J. (2010). Genre: An Introduction to History, Theory, Research, and Pedagogy. West Lafayette: Parlor Press.

Kovačević D. (2017). Contrastive Linguistic Analysis of Texts on Classical Music in English and Serbian and Its Possible Applications in Professional Environment and ESP, in Stojković N. (ed.) The Journal of Teaching English for Specific and Academic Purposes Vol. 5, No 1, 2017, pp. 35-48.

Kovačević D. (2018). Pedagogical Conceptualisation of Content Knowledge in Teaching Art Music Related ESP, in Stojković N. (ed.) The Journal of Teaching English for Specific and Academic Purposes Vol. 6, No 3, 2018, pp. 333-339.

Krzanowski M. and Day J. (2011). Teaching English for Specific Purposes: An Introduction. Cambridge: Cambridge University Press.

Paltridge, B, and Starfield S. (eds) (2013). The Handbook of English for Specific Purposes. Chichester, West Sussex: Wiley-Blackwell.

Plavša, D. (ed.) (1972). Muzička umetnost, Enciklopedijski leksikon - Mozaik znanja. Beograd: Interpres.

Richards J.C. \& Schmidt R. (2010). The Longman Dictionary of Language Teaching and Applied Linguistics. Fourth Edition. London: Pearson Education Limited. 